\title{
BAI' BITHAMAN AJIL, ALTERNATIF PEMBIAYAAN PERUMAHAN \\ PADA PERBANKAN SYARIAH
}

\author{
Oleh : \\ Lily R. Harahap \\ Fakultas Ekonomi Universitas IBA \\ Jalan Mayor Ruslan Palembang 30113
}

\begin{abstract}
ABTRACT
During this recent two decades, national economy sharia continiue growth. Though it just still smaller compare to the existing of conventional finance, it conscioused the growth of sharia finance currently has a significant enhancement. The positive and stable economy performance has given good opportunities to the development of sharia economy in Indonesia. The existence of syariah economy in Indonesia, who has a muslim mayority, is a new point of national economy history.

Sharia banking is one of the tools for developing national economy sharia. Many products offered by national sharia banking, which includes basic principles of implementation with profit sharing. One of them is Bai' Bithaman Ajil, which is the part of trading (Baiah). Bai' Bithaman Ajil product is expected as an alternative for society to choose sharia banking as a mediator in transaction, specially to fulfill production needs as well as consumption needs, whose transactions are done on a long-term credit.
\end{abstract}

\section{Keywords : syariah banking, bai’ bithaman ajil.}

\section{PENDAHULUAN}

Selaku makhluk hidup, adapun kebutuhan mendasar yang diperlukan oleh manusia mencakup pangan, sandang dan perumahan. Pada masa ini 3 hal mendasar tersebut ditambahkan lagi dengan memahami pentingnya kesehatan dan pendidikan yang baik. Dengan diperolehnya keperluan mendasar tersebut secara baik, maka akan menghasilkan suatu kehidupan yang baik pula.

Untuk memperoleh kebutuhan tersebut pembiayaan yang dilakukan bisa berupa pembiayaan yang dengan pembayaran sekaligus maupun dengan cara mengangsur. Perbankan Syariah, yang dalam prakteknya menganut prinsip syariah, yaitu aturan perjanjian berdasarkan hukum Islam antara bank dan pihak lain untuk penyimpanan dana 
dan atau pembiayaan kegiatan usaha, atau kegiatan lainnya yang dinyatakan sesuai dengan syariah, menawarkan suatu produk yang disebut dengan Bai' Bithaman Ajil.

\section{LANDASAN TEORI}

\section{Perbankan Syariah}

Perbankan dituangkan dalam Undang-Undang Nomor 10 tahun 1998 pasal 1 pengertian bank, bank umum dan Bank Perkreditan Rakyat disempurnakan menjadi: badan usaha yang menghimpun dana masyarakat dalam bentuk simpanan dan menyalurkannya kepada masyarakat dalam bentuk kredit dan atau bentuk-bentuk lainnya dalam rangka meningkatkan taraf hidup rakyat banyak. Sedangkan pengertian bank umum adalah bank yang melaksanakan kegiatan usaha secara konvensional dan atau berdasarkan prinsip usaha syariah yang dalam kegiatannya memberikan jasa dalam lalu lintas pembayaran. Serta pengertian Bank Perkreditan Rakyat Syariah (BPR-Syariah) adalah bank yang melaksanakan kegiatan usaha secara konvensional dan atau berdasarkan prinsip syariah yang dalam kegiatannya tidak memberikan jasa dalam lalu lintas pembayaran.

Secara umum, Perbankan Syariah atau Perbankan Islam adalah suatu sistem perbankan yang pelaksanaanya berdasarkan hukum Islam (syariah). Pembentukan sistem ini berdasarkan adanya larangan dalam agama Islam untuk meminjamkan atau memungut pinjaman dengan mengenakan bunga pinjaman (riba), serta larangan untuk berinvestasi pada usaha-usaha berkategori terlarang (haram).

Dari data statistik Otoritas Jasa Keuangan (OJK) per April 2017, total aset perbankan syariah mencapai angka Rp. 261,950 triliun. Dibandingkan periode satu tahun sebelumnya, sebesar Rp. 212,298 trilliun, aset perbankan syariah telah mengalami pertumbuhan sebesar 23,39 \%. Angka pembiayaan pada April 2017 mencapai Rp.109,870 triliun dimana tahun sebelumnya sebesar Rp. 82,915 triliun, telah mengalami pertumbuhan sebesar $32,50 \%$. Begitu juga dengan fungsi intermediasi perbankan syariah pun semakin meningkat. Financing to Deposit Ratio (FDR), yaitu rasio pembiayaan terhadap dana pihak ketiga, per April 2017 mencapai 88,11\%. Angka ini meningkat dari tahun sebelumnya yang mencapai $81,36 \%$. 
Dalam menjalankan fungsi jasa perbankan, bank syariah melakukan 3 fungsi yaitu :

1. Menghimpun dana : dengan akad wadiah dan akad mudharabah

2. Menyalurkan dana : dengan akad murabahah, akad bai' bithaman ajil, akad salam, akad isthisna, akad ijarah, investasi musharakah dan investasi mudharabah, pinjaman qardh.

3. Jasa Layanan : akad wakalah, akad kafalah, akad sharf, akad hawalah dan akad rahn.

\section{Bai’ Bithaman Ajil}

Bai’ Bithaman Ajil (BBA) merupakan bagian dari jual beli (Baiah). Baiah adalah prinsip saling menukar harta secara tetap diantara kedua belah pihak dengan memenuhi ketentuan-ketentuan yang dibenarkan syariat. Secara bahasa, Bai'Bithaman Ajil merupakan jual beli dengan penetapan harga yang akan dibayar kemudian. Sedangkan menurut istilah, Bai' Bithaman Ajil adalah jual beli untuk barang tertentu antara penjual dengan pembeli, dimana pemilik barang akan menyerahkan barang seketika, sedangkan pembayaran dilakukan dengan sistem cicilan dalam waktu yang disepakati bersama.

Pada piutang transaksi perbankan syariah, pihak bank bertindak sebagai penjual sedangkan anggota/ calon anggota pembiayaan bertindak sebagai pembeli dan akad yang digunakan adalah akad jual beli (Baiah). Harga jual yang diberikan kepada anggota/ calon anggota pembiayaan adalah harga pokok ditambah keuntungan atau margin yang telah disepakati kedua belah pihak. Harga jual yang telah disepakati tersebut, tidak berubah walaupun terjadi inflasi, deflasi, dan atau kenaikan suku bunga pasar.

Landasan Hukum Bai’ Bithaman Ajil terdapat dalam firman Allah dalam surat An-Nisa: 29 yang artinya:"Hai orang-orang yang beriman, janganlah kamu saling memakan harta sesamamu dengan jalan yang batil, kecuali dengan jalan perniagaan yang berlaku dengan suka sama suka di antara amu. Dan janganlah kamu membunuh dirimu, sesungguhnya Allah adalah Maha Penyayang kepadamu” . Kemudian landasan hukum Bai' Bitsaman Ajil, juga diperkuat dalam hadis Rasulullah saw, yang artinya: "Sesungguhnya Nabi Muhammad saw bersabda, ada tiga hal yang mengandung berkah, yaitu jual beli tidak secara tunai, muqaradah (mudharabah), dan mencampur gandum dengan jewawut untuk keperluan rumah tangga bukan untuk dijual. (HR. Ibnu Majah). 
Bai' Bithaman Ajil merupakan metode pembiayaan seperti metode pembiayaan murabahah. Hanya saja letak perbedaannya adalah pembiayaan Bai'Bithaman Ajil diperuntukkan memenuhi kebutuhan pembiayaan jangka panjang. Salah satunya adalah kredit syariah pembelian rumah.

\section{METODE PENGGUNAAN BAI’ BITHAMAN AJIL}

Gambar 3.1.

Transaksi Bai' Bithaman Ajil dengan 3 pihak

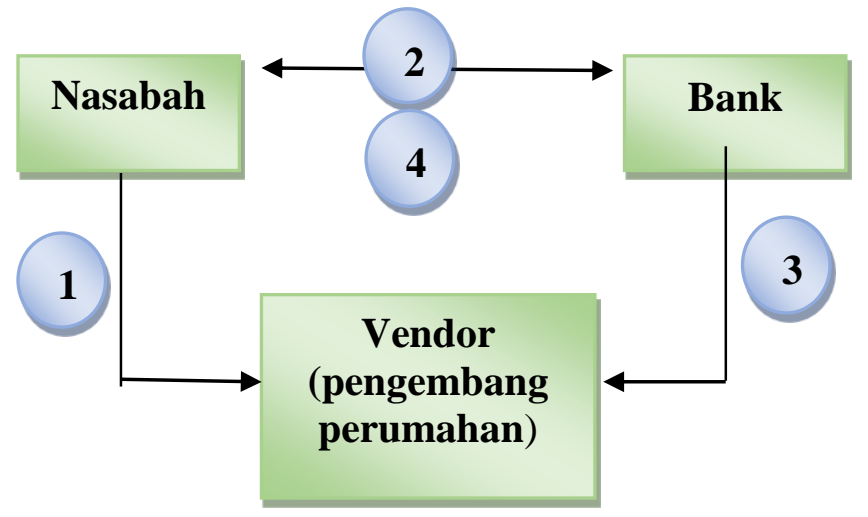

1) Nasabah menentukan rumah yang diinginkan, 2) Nasabah mendekati bank untuk mendapatkan pembiayaan, 3) Bank membeli rumah dari pengembang dan membayar penuh, 4) Bank menjual unit rumah tersebut kepada nasabah dengan harga jual yang sudah dinaikkan.

Gambar 3.2.

Transaksi Bai' Bithaman Ajil dengan 2 pihak

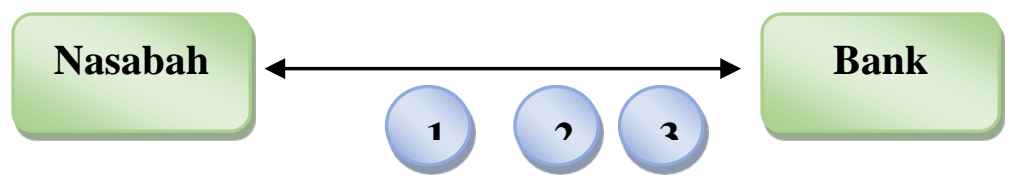

1) Nasabah menentukan rumah yang diinginkan dari persediaan rumah yang dimiliki bank, 2) Nasabah mendekati bank untuk mendapatkan pembiayaan, 3) Bank menjual unit rumah tersebut kepada nasabah dengan harga jual yang sudah dinaikkan. 
Gambar 3.3

Transaksi Bai' Bithaman Ajil dengan Nasabah sebagai Agen

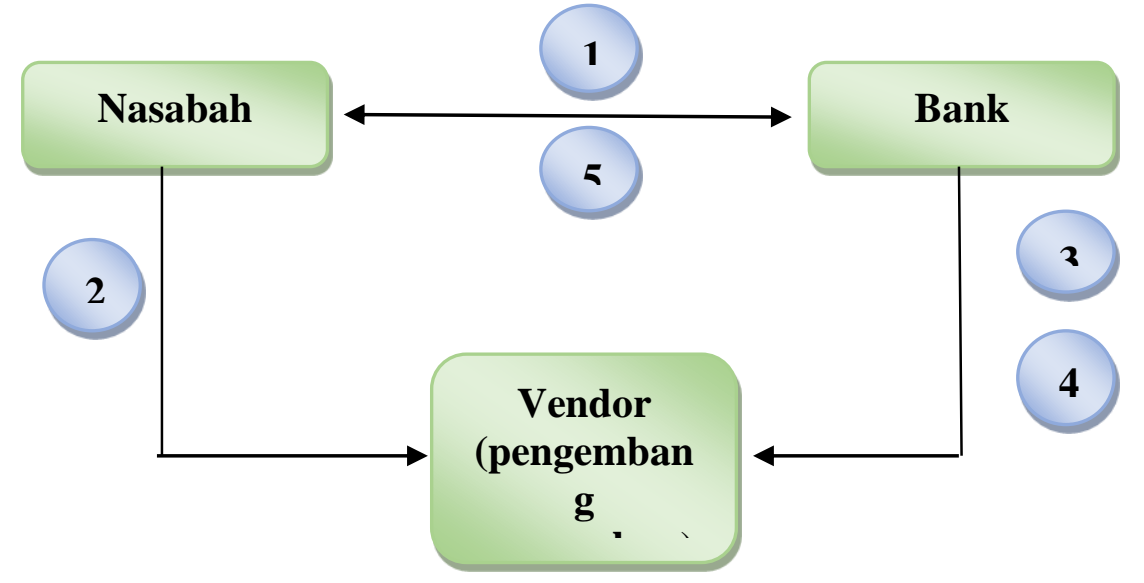

1) Bank menunjuk nasabah sebagai agen dalam satu kesepakatan (akad) dimana bank berjanji untuk menjual dan nasabah berjanji untuk membeli, satu rumah berdasarkan ketentuan dan kondisi tertentu dengan harga yang sudah dinaikkan. 2) Nasabah menentukan vendor dan memilih rumah mewakili bank (karena nasabah bertindak sebagai agen bank), 3) Vendor mengalihkan kepemilikan pada bank. Bank terlibat dalam proses ini untuk mengawasi prosesnya karena ada isu - isu hukum untuk ditangani, isuisu yang nasabah diasumsikan tidak mengetahuinya, 4) Bank membayar vendor, 5) Pada titik ini, kontrak keagenan berakhir. Bank menjual rumah tersebut kepada nasabah dengan harga yang sudah dinaikkan dan mengalihkan kepemilikan kepada nasabah. Setelah ini, nasabah membayar harga yang sudah dinaikkan itu dengan mencicil.

\section{PEMBAHASAN}

\section{Bai’ Bithaman Ajil Sebagai Alternatif Pembiayaan Perumahan di Indonesia}

Rumah merupakan kebutuhan pokok manusia, sebagaimana halnya makanan (pangan) dan pakaian (sandang). Dengan adanya kebutuhan yang penting terhadap rumah, maka tidak heran jika permintaan masyarakat akan rumah tiap tahun terus bertambah. Hal tersebut ditunjukkan oleh data statistik di bawah ini: 


\section{Grafik 4.1.}

Pertumbuhan Indeks Harga Properti Komersial (yoy)

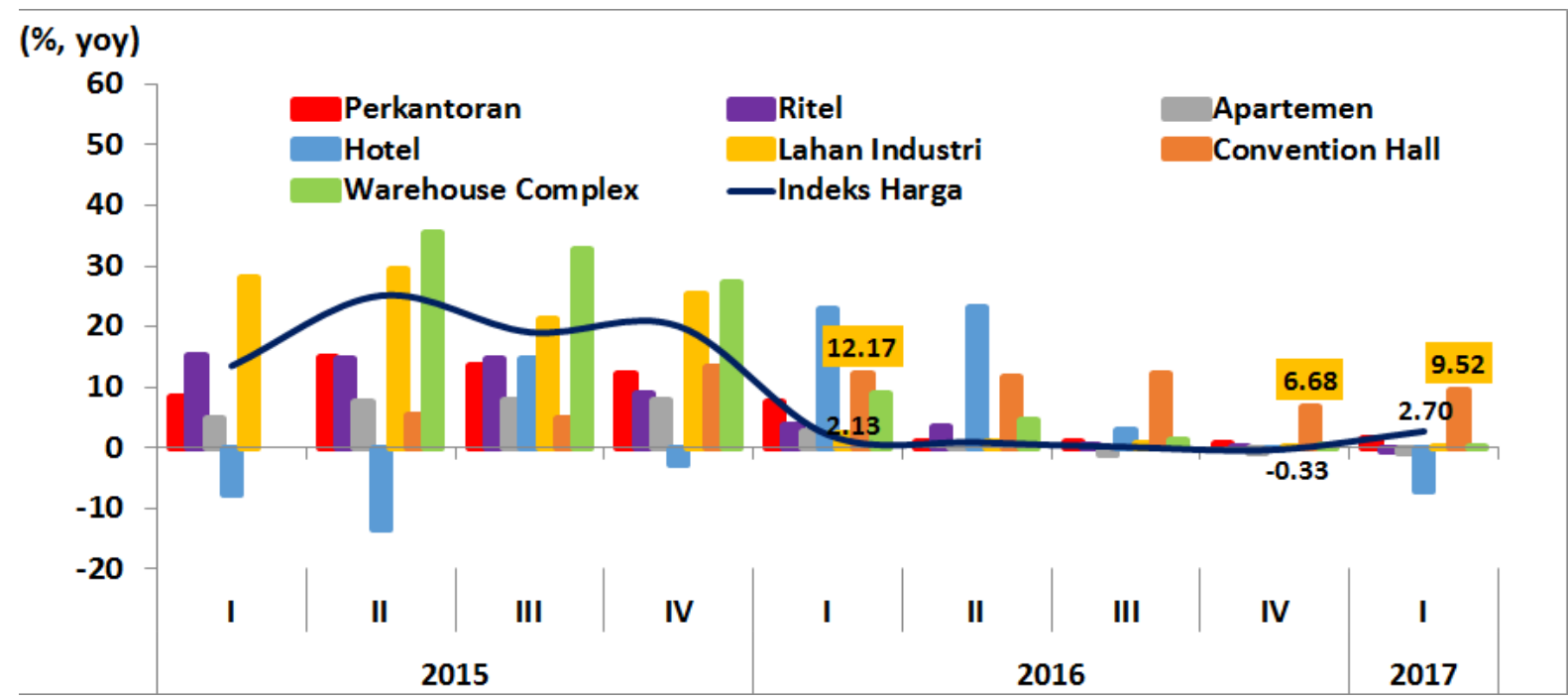

Sumber: www.bi.go.id (2017)

Dari grafik 4.1. dapat dijelaskan bahwa terjadi kenaikan harga properti komersial setiap tahunnya, terutama kenaikan harga dari convention hall sebesar 9,54\% di triwulan 1 tahun 2017.

\section{Grafik 4.2.}

Pertumbuhan Indeks Supply Properti Komersial (yoy)

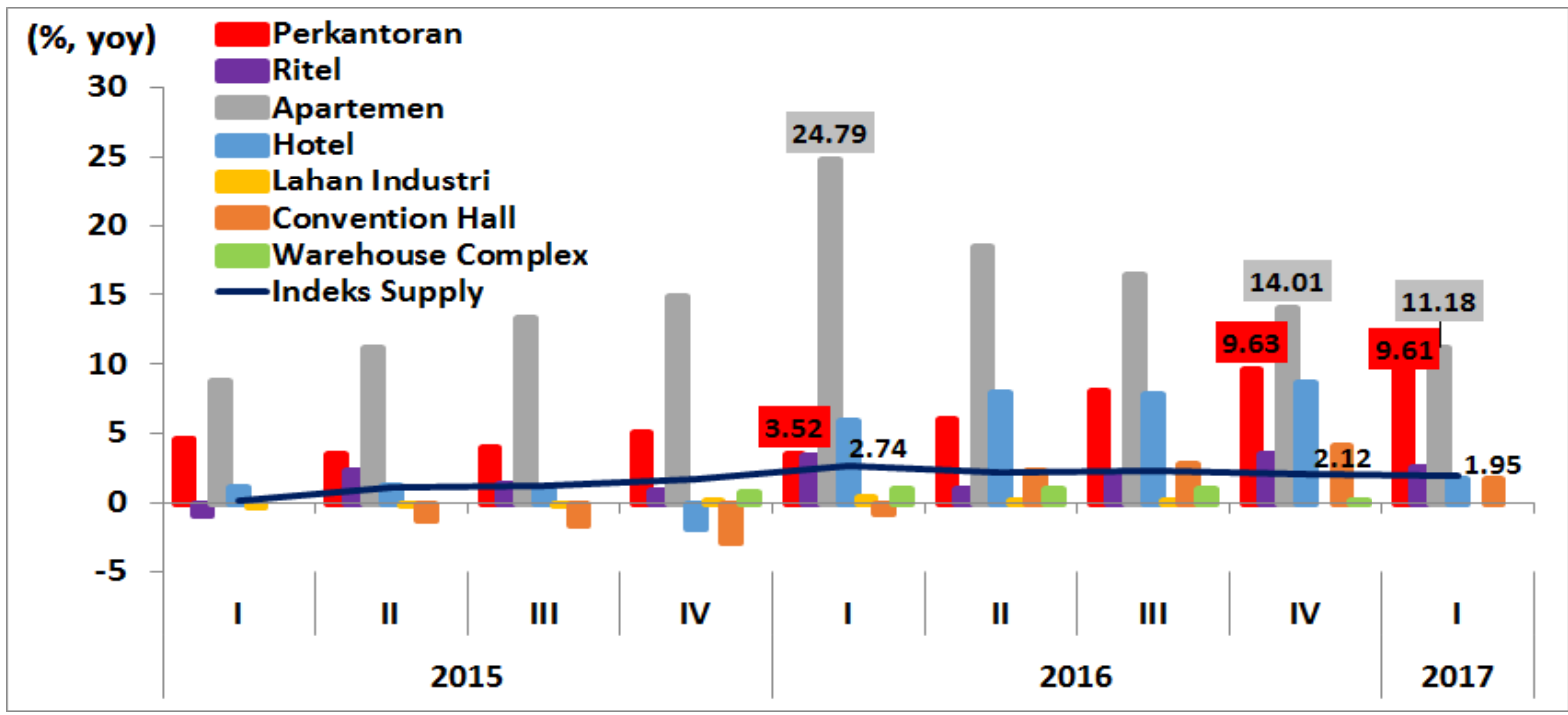

Sumber: www.bi.go.id (2017). 
Dari grafik 4.2. dapat dijelaskan bahwa pertumbuhan indeks supply properti komersial terutama terjadi pada segmen apartemen $(11,18 \%)$ dan segmen perkantoran $(9,61 \%)$.

Grafik 4.3.

Pertumbuhan Indeks Demand/Hunian Properti Komersial (yoy)

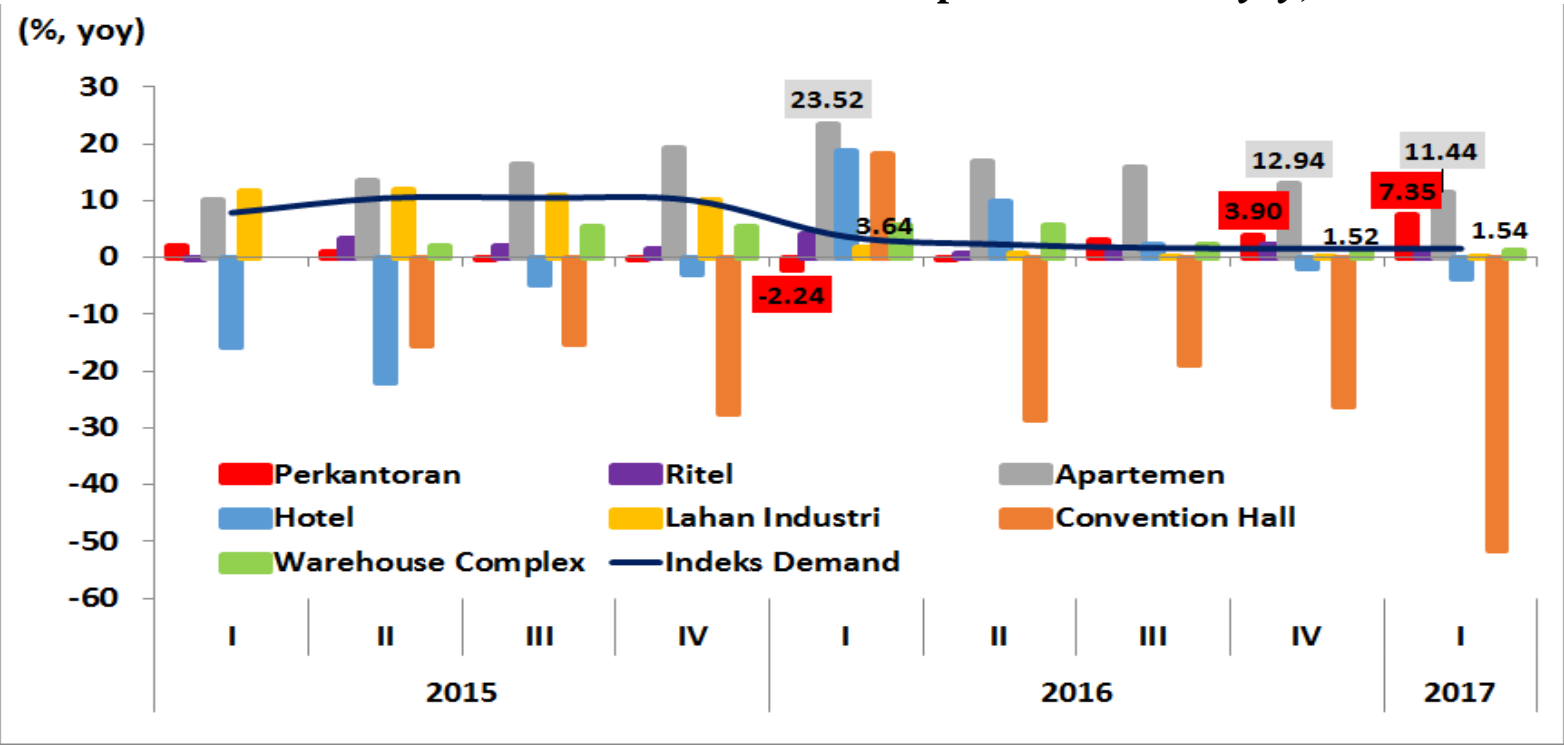

Sumber: www.bi.go.id (2017).

Dari grafik 4.3. dapat dijelaskan bahwa terjadi kenaikan indeks permintaan properti komersial setiap tahunnya, terutama terjadi pada segmen apartemen $(11,44 \%)$ dan segmen perkantoran $(7,35 \%)$.

Perkembangan investasi properti di Indonesia dapat dilihat dari salah satu faktor yang turut mempengaruhi meningkatnya bisnis proerti ini, adalah banyaknya konsumen yang tertarik dengan down payment (DP) yang sangat murah. Secara tidak langsung, penentuan DP ini ikut mempengaruhi permintaan akan properti. Maka tidaklah mengherankan jika banyak sekali developer atau pengembang yang menawarkan DP sangat murah dengan segala kemudahan. Hal ini bertujuan untuk menarik minat para konsumen sebanyak mungkin (http://www.paramount-land.com: 2017).

Dari ketiga grafik di atas terdata jelas tentang kenaikan bisnis properti komersial di Indonesia, yang dalam hal ini tentunya lembaga pembiayaan ikut berperan demi berjalannya bisnis tersebut. Hal ini menjadi peluang yang baik bagi produk Bai' 
Bithaman Ajil sebagai salah satu altrnatif pembiayaan. Di Indonesia, pembiayaan rumah dengan KPR syariah populer dengan menggunakan prinsip jual beli murabahah. Hampir sama dengan Bai' Bithaman Ajil, hana saja pembayaran angsuran dengan prinsip murabahah lebih pendek jangka waktunya dibandingkan dengan prinsip Bai'Bithaman Ajil.

\section{KESIMPULAN}

KPR Syariah merupakan pembiayaan yang digunakan untuk pembelian rumah secara kredit. Di Indonesia, KPR Syariah kebanyakan menggunakan akad murabahah. Seiring dengan meningkatnya permintaan akan kredit rumah, maka akad Bai' Bithaman Ajil bisa dipelajari untuk dijadikan alternatif pilihan. Selama ini penggunaan akad Bai' Bithaman Ajil dilakukan sepenuhnya di negara Malaysia. Adanya jangka waktu kredit yang lebih panjang yang ditawarkan oleh akad Bai' Bithaman Ajil dibandingkan akad murabahah, merupakan kelebihan yang bisa dijadikan alternatif pilihan.

\section{DAFTAR PUSTAKA}

Abdullah, Vicary,D. dan Chee, K. (2012). Buku Pintar Keuangan Syariah. Jakarta: Zaman.

Suma, A.M. (2013). Tafsir Ayat Ekonomi. Jakarta: Amzah

Venardos, A.M. (2015). Islamic Banking and Finance in South-East Asia

Ascarya, (2007). Akad dan Produk Bank Syariah. Jakarta: RajaGrafindo Persada

Nuryadin, H. (2014). BMT dan Bank Islam, Instrumen Lembaga Keuangan Syari'ah,. Bandung: Pustaka Bani Quraisy

Muhammad. (2010). Sistem dan Prosedur Operasional Bank Syariah,. Yogyakarta: UII Press

Wiroso. (2011). Produk Perbankan Syariah. Jakarta: LPFE, IBFI

Bank Indonesia. (2017). Perkembangan Properti Komersial. (online-11/7/17). www.bi.go.id

OJK. (2017). Statistik Perbankan Syariah. (online-11/7/17). Available www.ojk.go.id

Paramount Land. (2017). Perkembangan Investasi Properti di Indonesia. (online11/7/17). Available www.paramount-land.com 